\title{
Event Based Flood Inundation Mapping Under the Impact of Climate Change: A Case Study in Lower Kelani River Basin, Sri Lanka
}

\section{Gouri De Silva $^{1^{*}}$, Weerakoonb SB ${ }^{2}$, Srikantha Herath ${ }^{3}$}

${ }^{1}$ River and Environmental Engineering Lab, Department of Civil Engineering, Graduate School of Engineering, University of Tokyo, Tokyo, Japan

${ }^{2}$ Professor in Civil Engineering, Department of Civil Engineering, Faculty of Engineering, University of Peradeniya, Peradeniya, Sri Lanka

${ }^{3}$ Academic Director, United Nations University-Institute for Sustainability and Peace, Jingumae, Shibuya-ku, Tokyo, Japan

*Corresponding author: Gouri De Silva, PhD Student, River and Environmental Engineering Lab, Department of Civil Engineering, Graduate School of Engineering, University of Tokyo, Tokyo, Japan, Tel: +81-70-2821-9426; E-mail: gouri1981@gmail.com

Rec date: Feb 18, 2016; Acc date: Mar 02, 2016; Pub date: Mar 10, 2016

Copyright: (c) 2016 De Silva GT, et al. This is an open-access article distributed under the terms of the Creative Commons Attribution License, which permits unrestricted use, distribution, and reproduction in any medium, provided the original author and source are credited.

\begin{abstract}
The downstream low lying region of the Kelani River including the Colombo suburbs, experience severe inundation due to localized heavy rainfall events and high precipitation in the upper basin. Under the impact of climate change it is very likely that more frequent heavy rainfalls in tropics [1] will occur. Therefore it is extremely important to have a better understanding about future rainfall patterns and intensities in the basin and inundation extents of the low lying regions characterized by high population concentration and economic activities that form the suburbs of the commercial capital. This paper presents the extreme rainfalls occurrence potential and resulting flood inundation along the lower reach of Kelani River. Coarse grid atmospheric parameters provided by GCM models for A2 and B2 scenarios of IPCC [1] are downscaled to catchment scale by the application of Statistical Downscaling Model (SDSM). Flood discharge and inundation along the Kelani River reach below Hanwella was analyzed by the application of two-dimensional flood simulation model (FLO-2D). Inflow to the model at Hanwella, is estimated by the HEC- HMS model under future extreme rainfall events. Areas vulnerable for inundation under the above climate change scenarios are presented.
\end{abstract}

Keywords: Extreme rainfall; Flood inundation; Climate change; Kelani River

\section{Introduction}

The Intergovernmental Panel on Climate Change (IPCC) refers climate change as a change in the state of the climate that can be identified (e.g., using statistical tests) by changes in the mean and/or the variability of its properties and that persists for an extended period, typically decades or longer. Further it refers to any change in climate over time, due to natural variability or as a result of human activities. Greenhouse gas emissions which is the key cause of climate change, has increased due to human activities such as burning of fossil fuels, emission of industrial gases from the industrial zones, and change of land use practices such as urbanization and deforestation. In addition to this, increase of greenhouse gas emissions causes global warming and it will raise the sea level due to glacier melting.

According to the IPCC synthesis report [1], hot extremes, heat waves and heavy precipitation events (or proportion of total rainfall from heavy falls) will become more frequent all over the world and future tropical cyclones (typhoons and hurricanes) will become more intense, with larger peak wind speeds and more heavy precipitation associated with ongoing increases of tropical sea surface temperatures. Further, small islands, whether located in the tropics or higher latitudes, have characteristics which make them especially vulnerable to the effects of climate change such as sea-level rise and extreme events [2]. Being an island, Sri Lanka is also prone to the risk of climate change effects severely. Therefore, it is necessary to have better understanding about climate change issues and buildup the adaptive capacity to minimize its adverse effects.
Sri Lanka is situated in the Southern tip of India between North latitude of 60-100 and East longitude 800-820 extending over 65,610 $\mathrm{km}^{2}$. The development of extreme low pressure conditions in the Bay of Bengal also has direct impacts on the rainfall patterns in Sri Lanka. Anomalously high seasonal precipitation typically associated with $\mathrm{La}$ Nina phenomenon and cyclonic storms which originate from the Bay of Bengal are usually the main reasons for devastating floods in the island. The Island's central part is mountainous and when extending towards coast, the topography becomes plane. Sri Lanka has a tropical climate with two distinct monsoons as Northeast (December-March) and Southwest (May-September). During monsoon seasons Kelani, Kalu, Nilwala, and Gin river basins are subjected to severe floods. Frequently this flooding causes a serious damage to properties and lives in the flood plains of aforementioned river basins.

This paper discusses the frequencies of high intensity precipitation with their inundation extents in the lower Kelani River basin, under A2 (high emission) and B2 (low emission) scenarios produced by IPCC Special Report on Emissions Scenarios (SRES).

\section{Study Area}

Kelani River is the second largest river in Sri Lanka that originates from the central hills that flows to the west coast through the Colombo city. The basin is bound by Northern latitudes from $6^{\circ} 47^{\prime}$ to $7^{\circ} 05^{\prime}$ and Eastern longitudes from $79^{\circ} 52^{\prime}$ to $80^{\circ} 13^{\prime}$. The basin area is about 2230 $\mathrm{km}^{2}$. Topographically, the Kelani River basin can be distinctly characterized as upper and lower basins. The mountainous upper basin, that lies upstream of Hanwella gauge station, is about $1740 \mathrm{~km}^{2}$ and the lower basin (the main focus of this paper), downstream of Hanwella, which is on a flat-terrain and, is about $500 \mathrm{~km}^{2}$ (Figure 1). 
Page 2 of 4

The upper basin is mainly covered with the vegetation types such as tea, rubber, grass and forest while the lower basin is heavily urbanized. The basin receives the heaviest rainfall during the Southwest Monsoon period (May-September) and it is about $2400 \mathrm{~mm}$ of annual average. The river carries a peak flow of about $800-1500 \mathrm{~m}^{3} / \mathrm{s}$ during monsoons, to the Indian Ocean. The flood level gauge at Nagalagam Street (Colombo) defines the severity of the flood as; minor floods (level between $1.5 \mathrm{~m}$ and $2.1 \mathrm{~m}$ ), major floods (level is between $2.1 \mathrm{~m}$ and 2.7 $\mathrm{m}$ ), and severe flood (level exceeds $2.7 \mathrm{~m}$ ) [3].

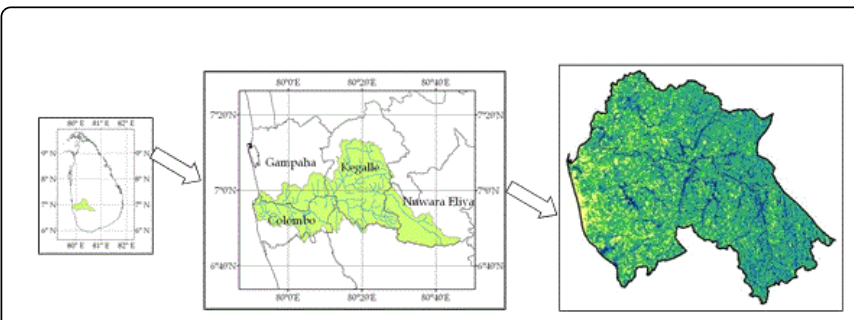

Figure 1: Kelani River basin.

\section{Methodology}

\section{Preparation of data and rainfall modeling}

The required topographic data and land use data were derived from the Department of Survey, Sri Lanka as 1:10,000 and 1: 50,000 map layers respectively and converted the contour data to DEM in Arc-GIS environment. Inflow hydrograph at Hanwella was generated by Hydrologic Engineering Center-Hydrologic Modeling System (HECHMS) for the rainfall generated for upper catchment by applying Statistical DownScaling Model (SDSM) and the rainfall of the lower catchment also generated by SDSM.

Statistical Downscaling Model (SDSM) which is designed to downscale global circulations model data into regional level, was applied to downscale precipitation for the catchment up to 2099 under A2 and B2 scenarios published by IPCC. Forecasted rainfall of the upper catchment by SDSM was used in HEC-HMS model to generate the flow at Hanwella. Numerous past studies have shown this model to provide accurate and useful results in flood related studies [4-6]. Frequency analysis of return period was carried out for 3day total rainfall of the upper catchment by forecasted data from 2020 to 2099, because the basin is about $1740 \mathrm{~km}^{2}$ and according to Clark unit hydrograph transformation the time of concentration in the whole basin (at the edge of the lower basin) is about 2.5 days, where one day rainfall may not be able to produce floods at lower catchment. However, one day rainfall of lower catchment can cause severe floods since the time of concentration at the edge of the lower basin from Hanwella is about 12 hours. Therefore, the daily rainfall forecasted from 2020 to 2099 was used for the frequency analysis of the lower basin.

The 3 day rainfall of 50 year and 100 year return periods of upper basin and daily rainfall of 50 year and 100 year return periods of lower basin were selected for flood and inundation analysis. Tables 1 and 2 illustrate the summary of frequency analysis for upper and lower basins respectively by the application of Gumble distribution.

\begin{tabular}{|l|l|l|}
\hline Return period/(yr) & A2 Scenario & B2 Scenario \\
\hline 100 & 429 & 420 \\
\hline 50 & 391 & 382 \\
\hline
\end{tabular}

Table 1: Day rainfall for upper basin.

\begin{tabular}{|l|l|l|}
\hline Return period/(Yr) & A2 Scenario & B2 Scenario \\
\hline 100 & 476 & 417 \\
\hline 50 & 425 & 377 \\
\hline
\end{tabular}

Table 2: Daily rainfall for lower basin.

\section{Inundation mapping}

Two-dimensional flood simulation model, FLO-2D was utilized to analyse inundation areas and map them. FLO-2D is simple volume conservation, two-dimensional flood routing model that distributes a flood hydrograph over a system of square grid element. It can be a valuable tool for delineating flood hazards, regulating floodplain zoning or designing flood mitigation. FLO-2D numerically routes a flood hydrograph while predicting the area of inundation and simulating flood wave attenuation [7].

The FLO-2D system consists of processor programs to facilitate graphical editing and mapping and components that simulation channel and floodplain detail. The Grid Developer System (GDS) generates a grid system that represents the topography as a series of small tiles. The FLO-2D model has components for rainfall, channel flow, overland flow, infiltration, levees and other physical features [8]. Flood routing in two dimensions is accomplished through a numerical integration of the equations of motion and the continuity equation [8].

$$
\begin{aligned}
& \frac{\partial h}{\partial t}+\frac{\partial h V}{\partial x}=\mathrm{i} \\
& S_{f}=S_{0}-\frac{\partial h}{\partial x}-\frac{V}{g} \times \frac{\partial V}{\partial x}-\frac{1}{g} \times \frac{\partial V}{\partial t}
\end{aligned}
$$

Where, h, V, i, $S_{\mathrm{f}}$ and $\mathrm{S}_{0}$ are flow depth, depth-averaged velocity, excess rainfall intensity, friction slope and bed slope respectively. The differential form of the continuity and momentum equations in the FLO-2D model is solved with a central, finite difference numerical scheme as one dimensional flow of channel and two dimensional flow of flood plain.

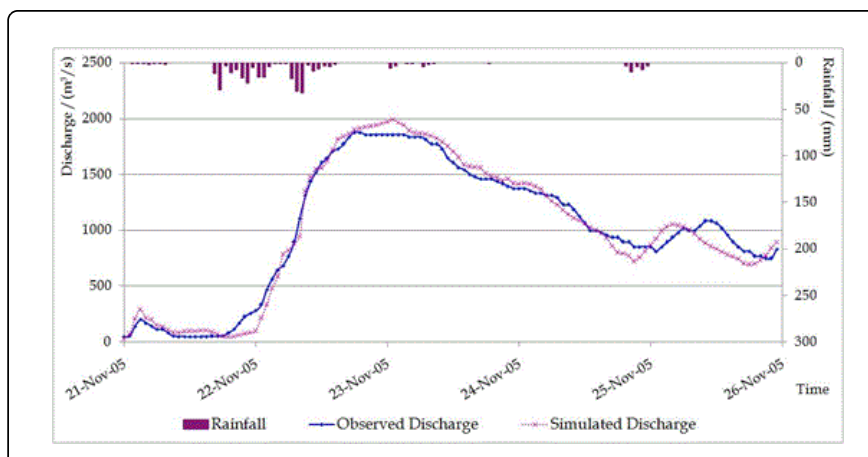

Figure 2: Time series of observed and simulated flow at Nagalagam Street gauging station during 2005 flood. 
Page 3 of 4

The GDS of FLO-2D was used to generate $250 \mathrm{~m} \times 250 \mathrm{~m}$ grids covering the lower basin area. Manning's coefficients over the basin were allocated according to the land use patterns. The model was calibrated for the extreme event occurred in November 2005, by comparing the flow at Nagalagam Street discharge gauging station (Figure 2).

The validation was carried out for the discharge at Nagalagam Street by using the events occurred in April-May 2008, May-June 2008 and May 2010. Normalized Objective Function (NOF), Nash-Sutcliffe efficiency $\left(\mathrm{R}^{2}{ }_{\mathrm{NS}}\right)$, and percentage bias $\delta_{\mathrm{b}}$ values were considered to justify the accuracy of results (Table 3 ).

\begin{tabular}{|l|l|l|l|}
\hline Event & NOF & $\mathbf{R}^{2}$ NS & $\boldsymbol{\delta}_{\mathrm{b}}$ \\
\hline April-May 2008 & 0.14 & 0.97 & $10.37 \%$ \\
May-June 2008 & 0.11 & 0.91 & $8.92 \%$ \\
May 2010 & 0.23 & 0.85 & $18.56 \%$ \\
\hline Average over validation events & 0.16 & 0.91 & 12.62 \\
\hline
\end{tabular}

Table 3: Goodness of fit for events used for validation.

The simulated flows show a sound agreement with observed flows. Further, in order to justify the inundation extents, Advanced Land Observing Satellite / Phased Array type L- band Synthetic Aperture Radar (ALOS/PALSAR) satellite, HH data set (operating at $\mathrm{C}$ band, incidence angle of $34^{0}, 12.5 \mathrm{~m}$ pixel size and approximate ground resolution of $25 \mathrm{~m}$ ), and flood inundation maps published by the Disaster Management Center (DMC) were used to compare the simulated inundation extents with the observed for events, May 2008 and May 2010, respectively.

For ALOS/PALSAR satellite data, two types of images were used to demarcate the flood inundated areas, as dry day image $\left(3^{\text {rd }}\right.$ March 2008) and an image taken during the flood event ( $3^{\text {rd }}$ June 2008) covering the study area. The processing was carried out in ERDAS IMAGINE 9.2 image processing software environment and compare with the simulated flood extents. The DMC dataset directly provide the inundated areas directly and it was compared with the simulated results (Figure 3).

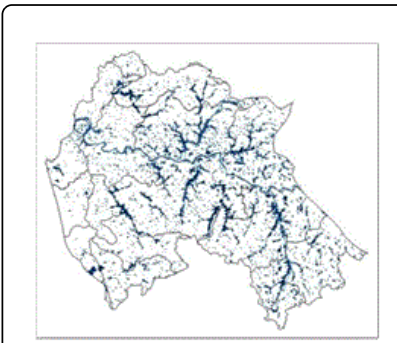

Observed inundation extent

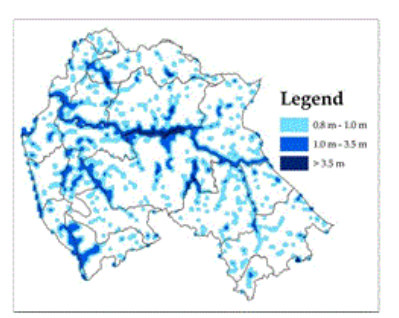

Simulated inundation extent
Figure 3: Inundation extents during the flood, May 2008.

The inundation extents were compared by considering the fraction of the domain classified correctly by the simulations, which was the method successfully utilized in past studies [9-11] and the equation 3 was used for calculation.

$$
F=\frac{S_{o b s} \cap S_{\text {mod }}}{S_{o b s} \cup S_{\text {mod }}} \times 100
$$

Where, $S_{\text {obs }}$ and $S_{\text {mod }}$ are set of domain sub regions (cells or pixels) observed to be inundated and predicted as inundated respectively and is the measure of fit. If the simulated extents exactly overlap with the observed extents, value is to be $100 \%$ and if no simulated extent overlaps with observed extents, value has to be 0 . The values for May 2008 and May 2010 events are 79\% and 73\% respectively which implies a good correlation.

\section{Results and Discussion}

The flood and inundation mapping in the lower basin was carried out using three day rainfall events of 50 year and 100 year return periods of upper basin and daily rainfall events of 50 year and 100 year return periods of lower basin under both $\mathrm{A} 2$ and $\mathrm{B} 2$ scenarios.

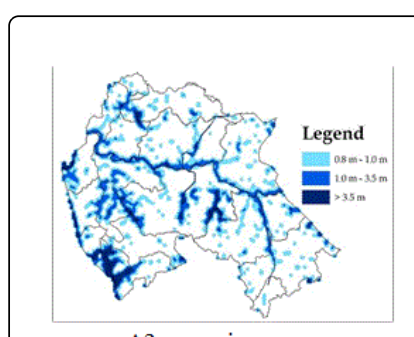

A2 scenario

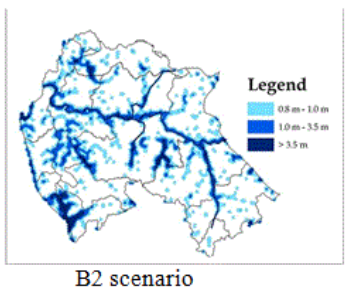

B2 scenario
Figure 4: Inundation extents due to 50 year return period rainfall.

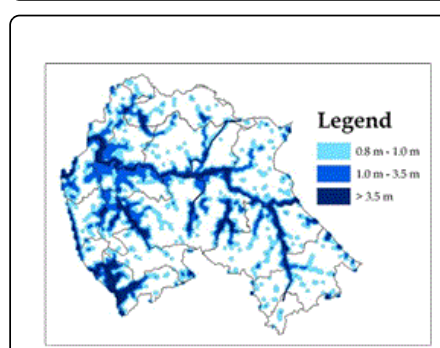

A2 scenario

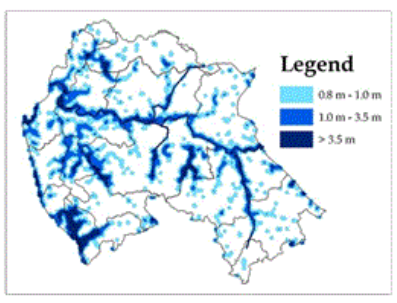

B2 scenario
Figure 5: Inundation extent correspond to 100 year return period rainfall.

Figure 4 shows that the flood corresponds to rainfalls of 50 year return period, causes inundation in Colombo district as well as Gampaha district. Kesbewa, Sri Jayawardanapura Kotte, Kaduwela, Kelaniya and Kolonnawa are the heights hazardous areas for 50 year return period floods under both $\mathrm{A} 2$ and $\mathrm{B} 2$ scenarios whereas it further expands to Dehiwala, Mount Lavinia, Thimbirigasyaya, Wattala, Mahara, Homagama and hanwella areas.

The inundation extends correspond to each flood event considered and the hazard status are shown in Table 4. Low hazardous means water depth is in between $1.5 \mathrm{~m}$ to $2.0 \mathrm{~m}$, moderate hazardous means water depth is in between $2.0 \mathrm{~m}$ to $2.7 \mathrm{~m}$ and high hazardous means water depth is greater than $2.7 \mathrm{~m}$ (Figure 5). 
Citation: Silva GD (2016) Event Based Flood Inundation Mapping Under the Impact of Climate Change: A Case Study in Lower Kelani River Basin, Sri Lanka. Hydrol Current Res 7: 228. doi:10.4172/2157-7587.1000228

Page 4 of 4

\begin{tabular}{|l|l|l|l|l|}
\hline \multirow{2}{*}{ Hazard status } & \multicolumn{4}{|c|}{ Vulnerable area/( $\left.\mathbf{k m}^{2}\right)$} \\
\cline { 2 - 5 } & $\mathbf{5 0}$ year return period A2 & $\mathbf{5 0}$ year return period B2 & $\mathbf{1 0 0}$ year return period A2 & $\mathbf{1 0 0}$ year return period B2 \\
\hline Low & 385.24 & 356.80 & 395.21 & 388.54 \\
\hline Moderate & 172.15 & 102.15 & 195.34 & 155.63 \\
\hline High & 25.18 & 18.56 & 50.14 & 39.52 \\
\hline
\end{tabular}

Table 4: Vulnerable areas for floods.

\section{Conclusions}

Rainfall in the Kelani basin under A2 and B2 scenarios [1] of climate change predictors were downscaled from GCM data using SDSM. Rainfall of 50 year and 100 year return period (by using forecasted data from 2020 to 2099) under A2 and B2 were designed. Flood hazard regions were computed under above extremes FLO-2D flow model. The outcomes of this research are useful for identifying the hazardous areas due to floods and could be helpful to develop the areas more vulnerable to floods in order to minimize the risk of damages to general public. Further flood warning systems can be developed and evacuation centres could be established in non-inundating areas to prevent the losses.

\section{References}

1. Tirpak D, Bernstein L, Bosch P, Canziani O, Chen Z, et al. (2007) Synthesis Report Climate Change. Fourth Assessment Report of IPCC.

2. Mimura N, Nurse L, McLean RF, Agard J, Briguglio L, et al. (2007) Small islands. Climate Change Impacts, Adaptation and Vulnerability. Contribution of Working Group II to the Fourth Assessment Report of the Intergovernmental Panel on Climate Change. Cambridge University Press, Cambridge.
3. Gunasekara IPA (2008) Flood Hazard Mapping in Lower Reach of Kelani River. Journal of Engineer 1: 1-5.

4. Ahrens SR, Maidment DR (1999) Flood Forecasting for the Buffalo Bayou using CRWR-PrePro and HEC-HMS(CRWR Report 99-6). Center for Research in Water Resources.

5. Anderson ML, Chen ZQ, Kavvas ML, Feldman A (2002) Coupling HECHMS with atmospheric models for prediction of watershed runoff. Journal of Hydrologic Engineering 7: 312-318.

6. Yanga ZL, Knebla MR, Hutchisonb K, Maidmentc DR (2005) Regional scale flood modeling using NEXRAD rainfall, GIS, and HEC-HMS/RAS: a case study for the San Antonio River Basin Summer 2002 storm event. Journal of Environmental Management 75: 325-336.

7. Tetra Tech Inc. (2004) Development of the Middle Rio Grande FLO-2D Flood Routing Model Cochiti Dam to Elephant Butte Reservoir.

8. O'Brien JS, Jorgensen CR, Garcia R (2009) FLO-2D Reference manual, FLO-2D Software Inc. Nutrioso.

9. Aronica G, Bates PD, Horritt MS (2002) Assessing the uncertainty in distributed model predictions using observed binary pattern information within GLUE, Hydrological Processes Journal 16: 2001-2016.

10. Horritt MS (2006) A methodology for the validation of uncertain flood inundation models. Journal of Hydrology 326: 153-165.

11. Nandalal HK (2011) Flood risk management incorporating stakeholder participation and climate variability. 